\title{
岩盤内の地山応力と地学的に推定される 地殼応力との関連についで
}

\author{
平松 良 雄 ${ }^{* *}$ 岡 行 俊** \\ 伊藤英 文 ${ }^{* *}$ 田 中 豊 $* * * *$
}

\section{The Correlation of the Rock Stress Measured in situ and the Tectonic Stress Inferred from Geological and Geophysical Studies}

by

\author{
Yoshio Hiramatsu, Yukitoshi OKa \\ (Faculty of Engineering, Kyoto University, Kyoto) \\ Hidebumi ITô \\ (Faculty of Home Economics, Kyoto Women's University, Kyoto) \\ and Yutaka TANAKA \\ (Faculty of Science, Kyoto University, Kyoto)
}

\begin{abstract}
On designing and performing underground excavation works it is desirable to measure the initial rock stress as one of fundamental data. Recently in the field of mining and civil engineering the rock stress is being measured by the stress relief technique. On the other hand, the tectonic movements, particularly the direction of stress and the strain rate, have been clarified by geological and geophysical investigations. The present paper first describes the method for estimating the tectonic stress. Subsequently, it mentions the fact that the initial rock stresses measured at the sites of Shintakasegawa and Okutataragi underground power stations are connected closely with the tectonic stresses in the respective districts.

From these investigations, it has been found that the axis of the maximum rock stress nearly coincides with that of the maximum tectonic stress. Though the experiences in determining rock stress have revealed that the stress obtained varies from one point to another and that the accuracy is not high, it may be concluded that the rock stress measured is reliable to some extent.

(Received Jan. 17, 1974)
\end{abstract}

\section{1 緒言}

地下構造物の合理的な設計・施工を行なら上に, 岩 盤中に空洞開さく以前に存在している応力すなわち地 山応力の状態を測定して，それを基礎資料の一つとし て考虑に入れることが望ましい，このため最近地山応 力の実測が盛んに行なわれるようになった。一方，地 質学拉よび地球物理学の分野でも，最近とれぞれ独自 の方法で, 日本各地の地殼の応力方向とひずみ速度が, 次第に明らかにされてきている。

筆者らは，長野県大町市の東京電力新高瀬川地下発 電所建設工事の際，地山応力測定に協力した。また関

* 原稿受理 昭和49年 1 月17日

** 正 会 員 京都大学工学部 京都市左京区吉田本町

*** 正会員 京都女子大学家政学部 京都市東山区東山七条

**** 正 会 員 京都大学理学部 京都市左京区北白川追分町
西電力から, 兵庫県朝来町の奥多々良木発電所建設の 際行なわれた地山応力測定の資料の提供を受けた。こ れらの地域は地質学的に古い基盤岩であり, 両地域の 地殼の主応力方向は地学的方法で推定がつく. 従来, 岩盤内の応力測定は，その信頼性を検証ず手段がな い点に悩みがあったが，この機会に，上記の二つの地 下発電所の付近の応力測定結果と地学的方法により推 定される地款応力とを比較してみた。

\section{2 応力解放による地山応力測定法}

地山応力は，ボアホールの直径抒よび孔軸方向のひ ずみの変化を測定する応力解放法によって決定される。 測定操作は, Fig. 1 (上) に示すように, 坑壁よりさ 〈孔された大さいボアホールの奥に小さいボアホール を作り，その中に計器を設置し，つぎに，同図（下） に示すように，小さいボアホールの外側をオーバュア 
リングして, 計器のまわりの応力を解放し, そのとき 起こる変形を測定するのである．このとき使用される
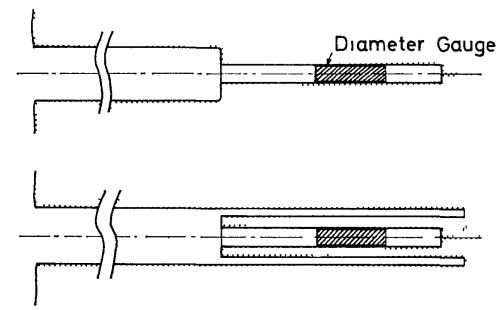

Fig. 1. Schematic representation of measurement of in situ rock stress. Upper : Setting of borehole gauge. Lower : Overcoring for stress relief.

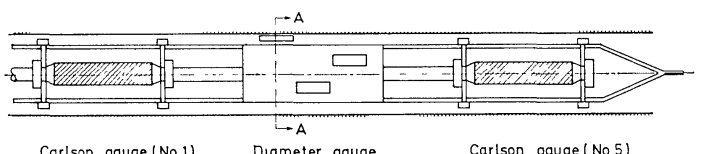

Carlson gauge ( No 1) Diameter gauge Carlson gauge ( No 5)

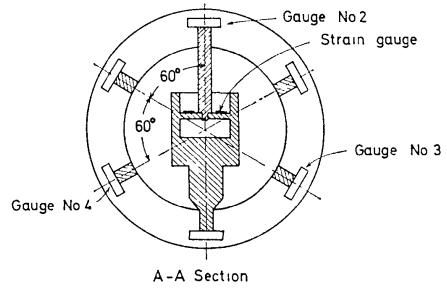

Fig. 2. Measuring apparatus of diametral and longitudinal deformations of borehole on the stress relief method (after Mimaki).

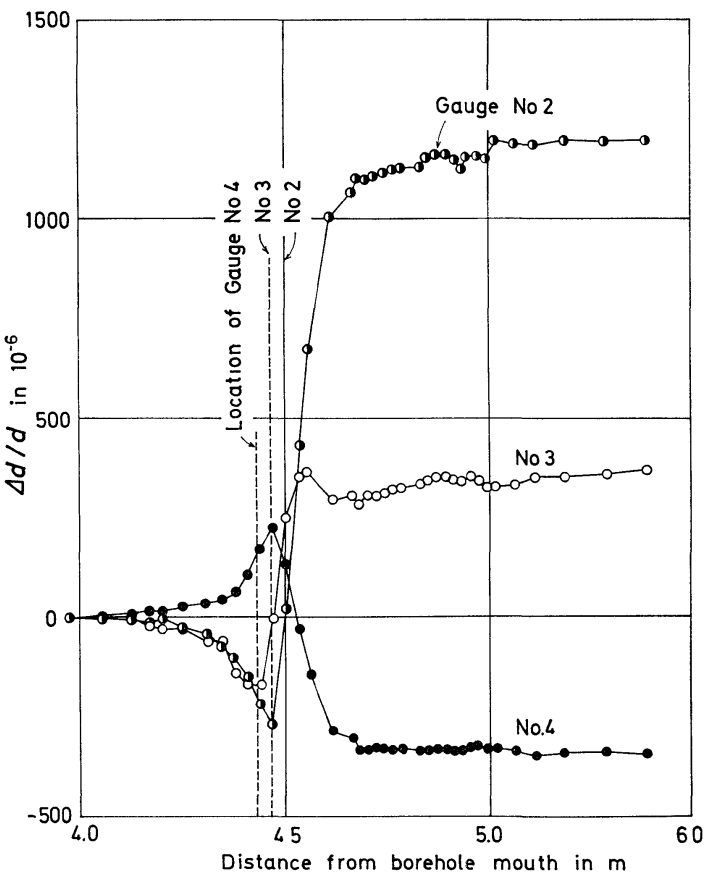

Fig. 3. An example of diametral deformation change with the progress of overcoring (after Mimaki).
計器の一例はFig. 2 のようで, 3 方向の直径変化 ${ }_{i} \Delta d_{i}$ および孔軸方向のひずみが測定されるようになってい る. Fig. 3 はオーバコアリングの進行に伴ら $\Delta d_{2} / d$ の 変化の一例を示す。.

\section{3 地学的な地殼応力推定方法}

この研究で，地殼応力の方向を推定するのに，次の 資料や方法を用いた。

（1）岩盤中に発達している裂かや断層などを地質構 造生成時のすべり面と仮定すれば，当時の地殼応力状 態が推定できる。たとえば，すべり面が活断層である 場合には現在の応力状態が推定できる. Fig. 4のよう に，三つの圧縮主応力によって，共役的な 2 方向に発 達するすべり面が生ずると，共役すべり面の交線の方 向は中間主応力軸 $p_{2}$ の方向と一致し, $p_{1}, p_{3}$ の方向 は共役すべり面のなす二つの角をそれぞれ二等分する 方向と一致する。また，すべり面で分けられる四つの ブロックは，相対的に $p_{3}$ の方向に伸び， $p_{1}$ の方向に 縮さ。野外で見いだされた共役すべり面から，この原 理に基ついて, 主応力の方向をステレオ投影図上で求 めるのである。
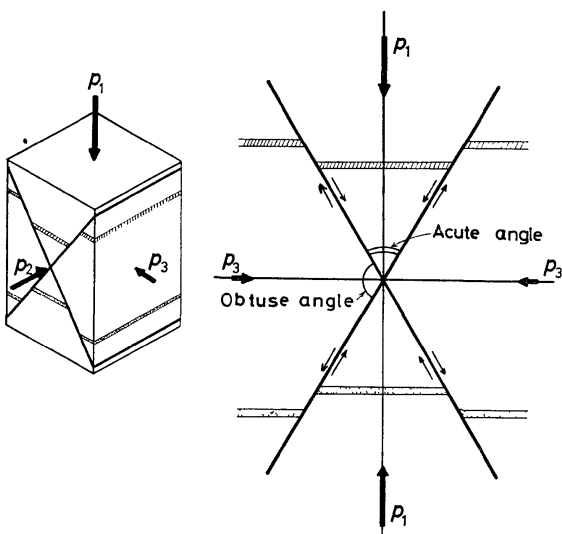

F19. 4. Relation between conjugate slip planes and directions of tectonic principal stresses.

（2）わが国では，新旧二回の一等三角測量により， 約60年間の全国三角点の水平変位が明らかにされてい る。その結果から，国内の汪とんぞの地域について平 均主ひずみが計算されている。 その一例をFig. 5 に示 す．この結果は地殼応力の状況をよく反映していると 思われる。

（3）地震波は $\mathrm{P}$ 波（縦波）， $\mathrm{S}$ 波（横波）打よび表 面波の順に観測点に到達する。観測された $\mathrm{P}$ 波には， その初動が押しの場合と引きの場合がある。いま，一 つの球面すなわら震源球を考光，多くの観測所で観測 された $\mathrm{P}$ 波を震源球上に引きもどして，押し引き別に プロットすると, それらの点は, Fig. 6 のように, 震 源を含み互いに直交する二つの平面（節面 Noda1 


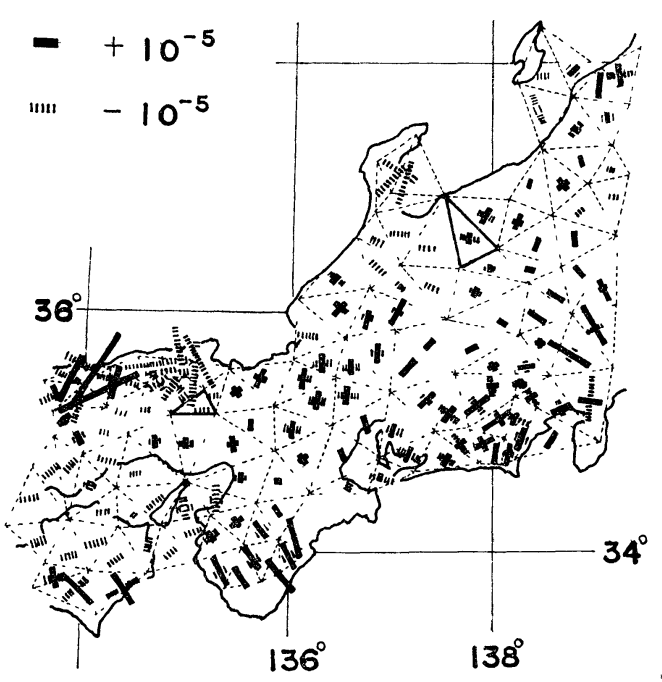

F1g. 5. Major and minor principal axes of horizontal strain in central Japan for the last 60 years, calculated from the results of the first order triangulation (after Harada and Kasai).

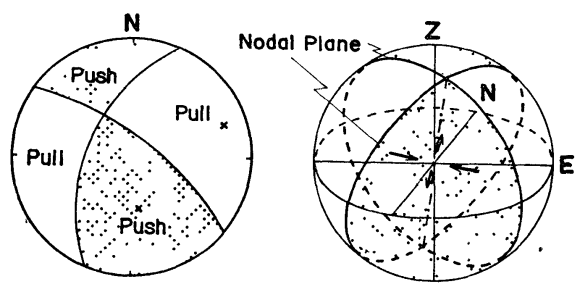

Fig. 6. Push-pull distribution 'of initial motion of seismic $P$ wave and nodal lines on lower hemisphere of stereographic projection (left) and schematic diagram showing earthquake generating force and nodal planes (right).

plane）で分けられた四つの部分に交互に現われる。 節面の一方が断層面であると考学られている。な和， このよらな分布を説明するためには，震源に拈いて互 いに直角な方向に張力と圧縮力が働いたものと考えれ ばよい (Fig. 6 の右図). 圧縮力の方向を起震力の方 向という。この方向は; 地域的に系統性がみられ，多 くの場合, 地域の最大主応力方向とみなされている.

\section{$4 \cdot 1$ 地山応力}

\section{4 新高瀬川発電所付近の応力}

この発電所は, Fig. 7 (b)に示すように, 急峻な山岳 地帯の被り約 $250 \mathrm{~m}$ の岩盤中に建設されつつある．付 近の地質は花崗閃緑岩, 斑状細粒閃緑岩执よび花崗岩 である(Fig. 8(a))。 。た，この付近の断層群として， 最も近くに猪の口, 少し離れて葛, さらに離れて高瀬 川等の断層がある (Fig. 8(b)). また東方約 $10 \mathrm{~km}$ に 糸魚川一静岡構造線がある。

地山応力測定は地下空洞開さくに先立って行なわれ た. 測定箇所は，Fig. 7 (a) に示す 2 本の調查坑上の No. 2〜4 の三つの地点で, 断面図に示すように, ほ

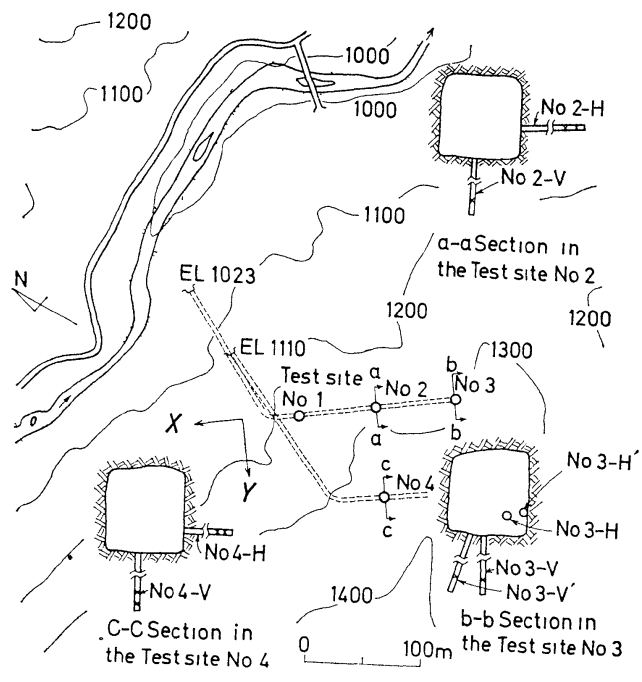

(a)

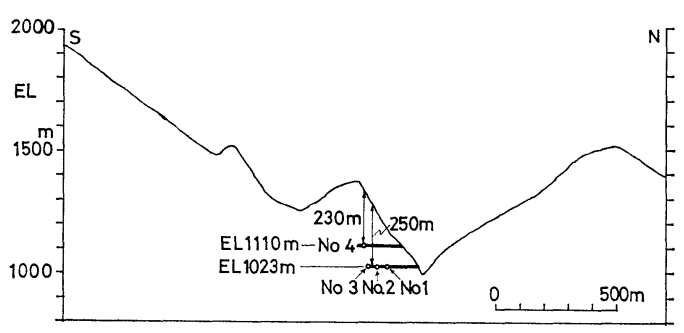

(b)

Fig. 7. (a) Plan of test area and exact sections of test sites and (b) N-S section through test site No. 2 in Shintakasegawa underground power house.

ぼ水平拈よび鉛直の 8 本のボアホールを掘さくし, そ れぞれFig. 2 の計器が埋設されて, 合計14点で測定が 行なわれた. 測定された直径変化から適当な 3 組以上 の組合せを多数（約 300）選び，抒の抒のの組合せに ついて観測方程式を立てて, 地山主応力 $\sigma_{1}{ }^{*}, \sigma_{2}{ }^{*}$, $\sigma_{3}{ }^{*}$ が計算された. これらのらち, 確かと思われる主 応力方向の一部を下半球のステレオ投影図上にプロッ トすると, Fig. 9(a)のよらになる。この外, 孔軸方向 のひずみの測定值やディスキング現象などを考慮に入 れて, 同図(b)のように地山応力を決定した．最大主応 力 $\sigma_{1} *$ は, 水平に近く, 注東西の圧縮力で, その 大きさは $100 \sim 180 \mathrm{~kg} / \mathrm{cm}^{2}$ である. 中間主応力 $\sigma_{2}{ }^{*}$ は注洼鉛直で被り圧に近く, 最小主応力 $\sigma_{3}{ }^{*}$ は零に近 く谷側に向いている.

\section{$4 \cdot 2$ 地款㐫力}

上述の地山応力測定結果に対して地殸応力を検討す ると, 次のようである。すず, 断層解析について述べ よう. Fig. 8(b)に示すように, 猪の口断層と葛断層は 共役と思われるので，これらから主応力方向を求める。 同図の上位に示すステレオ投影図のような $p_{1}, p_{2}, p_{3}$ 

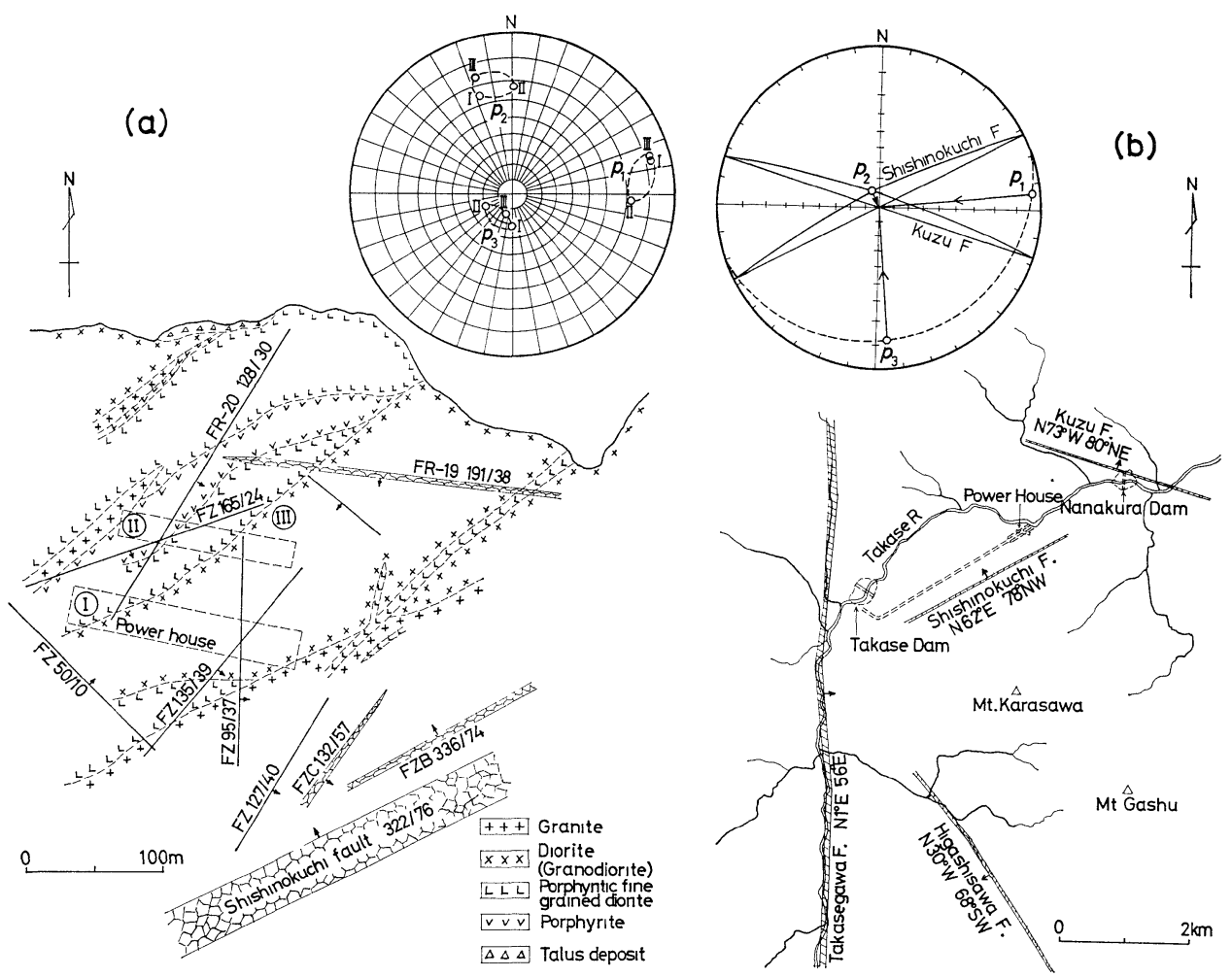

Fig. 8. (a) Directions of tectonic principal stresses (lower hemisphere) deduced from conjugate shear fissures developing in adits at the location I, II and III shown in the geologic map of Shintakasegawa power house area, and (b) those from the assumed set of Shishinokuchi and Kuzu faults.

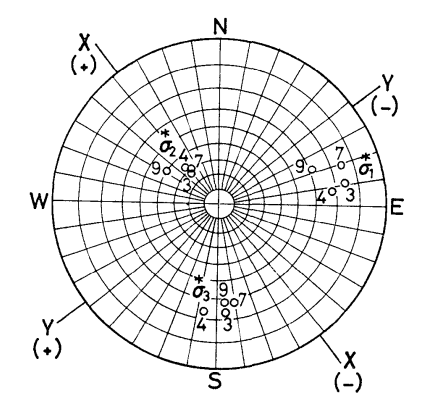

(a)

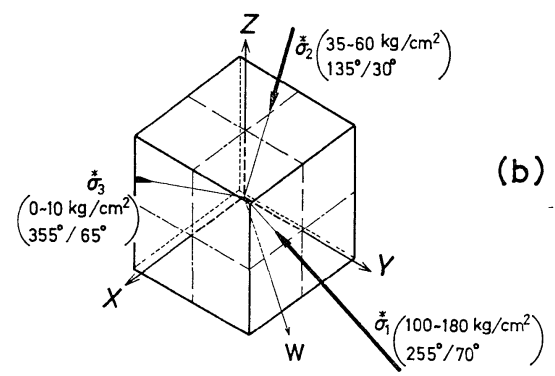

Fig. 9. Directions and magnitudes of principal rock stress in Shintakasegawa power house determined by the stress relief method. ((a): stereographic projection on lower hemisphere)
の方向を得る。これらは $\sigma_{1}{ }^{*}, \sigma_{2}{ }^{*}, \sigma_{3}{ }^{*}$ の方向とほぼ 一致している.さらに, Fig. 8 (a) に示す地山応力測定 箇所と㴗湆同一の 3 地点で, ずれを伴う裂か，すなわ ち，その表面に鏡肌や粘土シームにずれが認められる せん断裂かの傾斜方位が調査され, 共役せ九断面の密 度分布がとられた。これらの結果から, 地殼応力の主 応力軸が求められた. その結果はFig. 8(a)の上位のス テレオ投影図の破線内の範囲に $p_{1}, p_{2}, p_{3}$ の方向が ある。これらと $\sigma_{1}{ }^{*}, \sigma_{2}{ }^{*}, \sigma_{3}{ }^{*}$ の方向とを比較すると， 最大主応力 $p_{1}$ と $\sigma_{1}^{*}$ とはよく一致している. しかし, 中間括よび最小主応力は，傾斜が約 $50^{\circ}$ 異なっている.

つぎに, Fig. 5 によって, 高瀬川付近の測地学的に 推定される主ひずみをみると，東西方向の圧縮ひずみ である。

さらに, 地震学的な検討を行なう. Fig. 10 は浅発 地震の起震力の方向を, 市川の研究結果から引用した ものである. この付近には最近松代群発地震が発生し た。この図からわかるように, 泳湆東西方向に起震力 が働いたものが多いことが認められる。

\section{5 奥多々良木発電所付近の応力}

\section{$5 \cdot 1$ 地山応力}

発電所付近の地形は Fig. 11 左に示すようで，その 


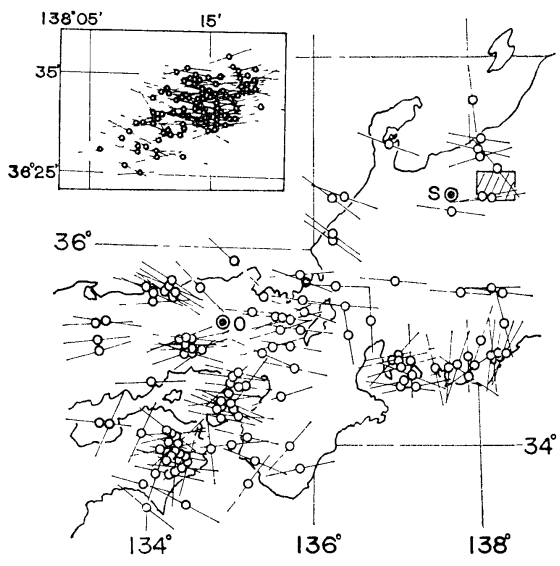

Fig. 10. Directions of earthquake generating forces of very shallow earthquakes in central Japan (after Ichikawa), S : Shintakasegawa, O : Okutataragi.

地質は石英粗面岩質角砅岩を主体として, 花崗斑岩拉 よび輝緑岩の岩脈を介在しているマッシブな岩盤であ る. 地山応力測定箇所は同図右のようで, 孔軸方向の ひずみが測定された。発電所空洞の長軸方向に直交す る水平軸を $x$ 軸, 鉛直に $z$ 軸をとると, 得られた結果 は，同図にひずみ計位置とともに示されているように， $\varepsilon_{x}=250 \times 10^{-6}, \varepsilon_{z}=90 \times 10^{-6}$ であり， $\varepsilon_{x}$ が $\varepsilon_{z}$ よりは るかに大きいことが注目される。また, 採取された岩 石コアについての試験から， ヤング率 $E=5.5 \times 10^{5}$ $\mathrm{kg} / \mathrm{cm}^{2}$ およびポアソン比 $\nu=0.25$ が得られている. これらの結果から 3 次元的な地山応力を決定するのは, データ不足のため不可能である。いま， $x, y, z$ 軸

*1 関西電力奥多々良木水力発電所建設所の教示による.
が主応力軸であり, $\sigma_{x}{ }^{*}=\sigma_{y}{ }^{*}$ の場合と, $\sigma_{y}{ }^{*}=0$ の場 合とを仮定すると, 前者では $\sigma_{x}^{*}=235 \mathrm{~kg} / \mathrm{cm}^{2}, \sigma_{z}{ }^{*}$ $=167 \mathrm{~kg} / \mathrm{cm}^{2}$, 後者では $\sigma_{x}{ }^{*}=160 \mathrm{~kg} / \mathrm{cm}^{2}, \quad \sigma_{z}{ }^{*}=90$ $\mathrm{kg} / \mathrm{cm}^{2}$ となる。一方, 被り圧から考光ると, $\sigma_{z}^{*}$ は $65 \sim 85 \mathrm{~kg} / \mathrm{cm}^{2}$ と推定される。この点を考慮し, ヤン グ率を測定值よりいくぶん小さくとることにし， $\sigma_{x}{ }^{*}$ $=150 \mathrm{~kg} / \mathrm{cm}^{2}$ 程度と判断する.
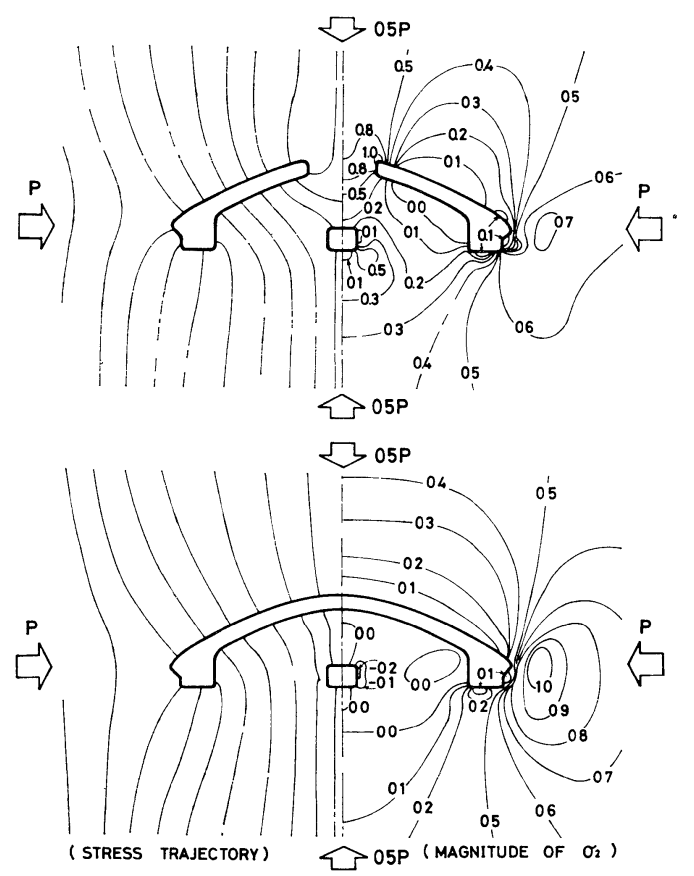

Fig. 12. Trajectories and contourlines of theoretical minor principal stress in rock before and after removing the top part on arched crown excavation in Okutataragi power house.
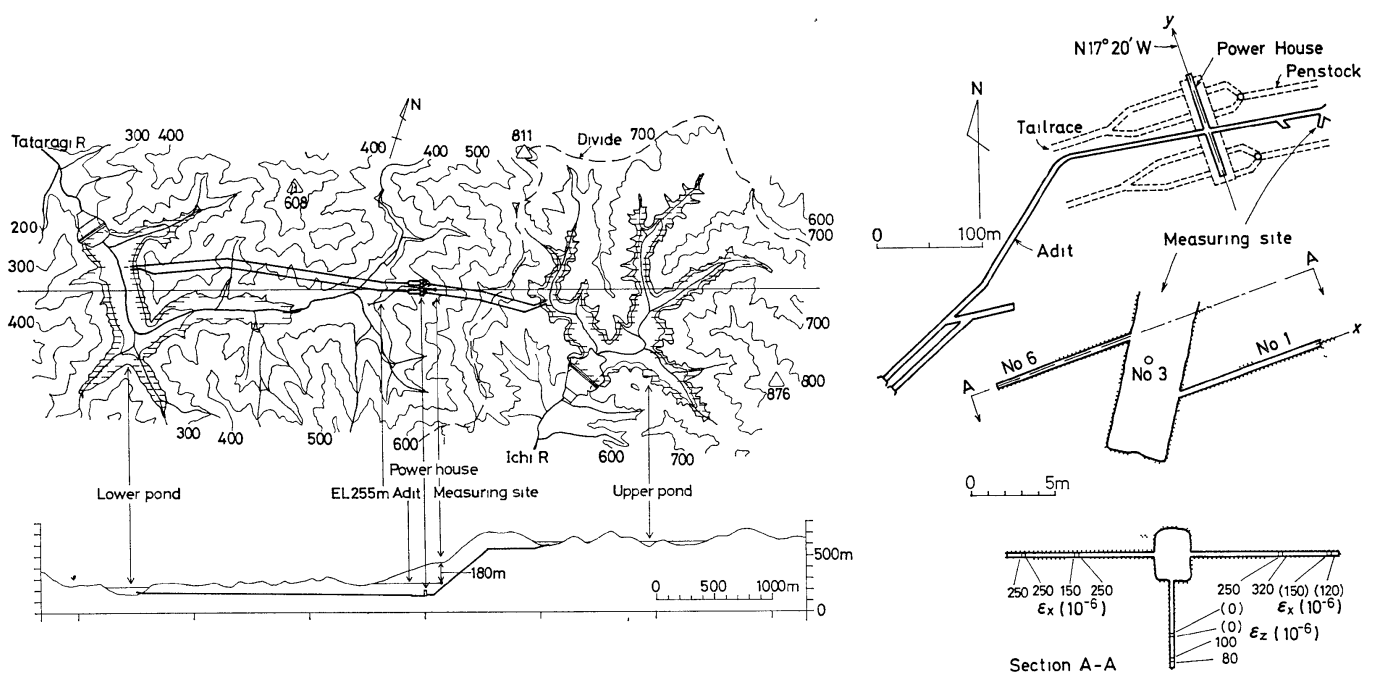

Fig 11 Topography of Okutataragi underground power house area (left), situation of test area and the values of longitudinal strain of borehole obtained by the stress relief method (right). 


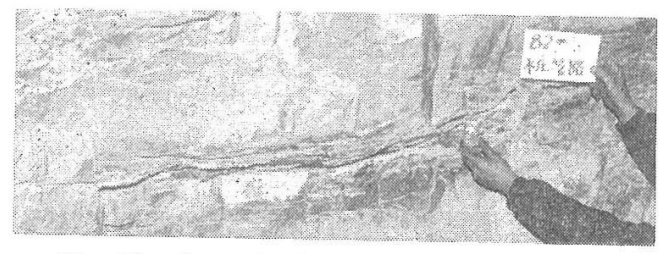

Fig. 13. Large horizontal cracks generated on both wall sides of center heading after removing the top part on arched crown excavation in Okutataragi power house (offered by the Kansai electric power Inc.)

参考のため,アーチ部掘さくの末期に起こった現象 述べて敃こう。この空洞は幅 $20 \mathrm{~m}$, 高さ $48 \mathrm{~m}$, 奥

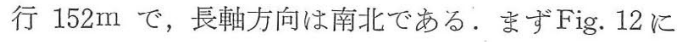
示すように 3 本の導坑が作られ, つづいてアーチ部の 掘さくが二,三箇所から進められた。前㣪の掘さくが 終わり，残された部分が取り払学れた翌日，中央導坑 の両側壁に水平なき裂が 20〜30 m にわたって発生し た (Fig. 13 参照).Fig. 12 は，アーチ部の掘さくが 一部分残された時期（上）之完全に掘さくされたとき （下）の岩盤内の $\sigma_{2}$ を有限要素法で計算したもので ある、ただし， $\sigma_{x}^{*}=p ， \sigma_{z}^{*}=p / 2$ 之仮定している。上 図では中央導坑側壁に圧縮応力が現われているが，下 図では約 $0.3 p$ の引張応力が坐じている。したがって， $p=150 \mathrm{~kg} / \mathrm{cm}^{2}$ とすると, 導坑側壁には約 $45 \mathrm{~kg} / \mathrm{cm}^{2}$ の引張応力が生じたことになる。ここの岩石の引張強 度は $54 \mathrm{~kg} / \mathrm{cm}^{2}$ 程度であることから考光ると、この上 らなき裂が生じたことが納得できる。いいか光机ば， このような現象が起こることは， $\sigma_{z}^{*} よ り \sigma_{x}^{*}$ の方が

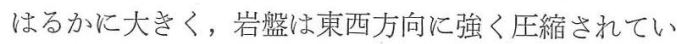
たことの一つの証拠と考光られる。

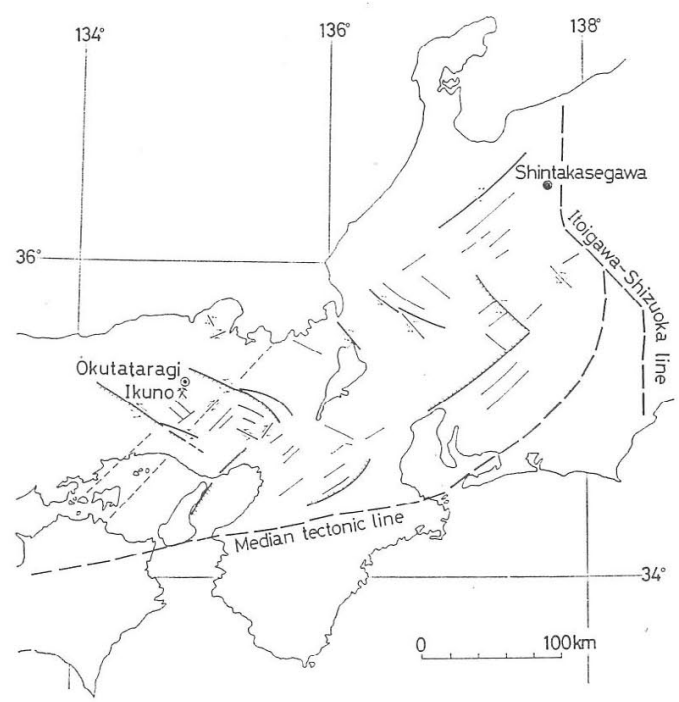

Fig. 14. Conjugate sets of strike-slip faults in Quaternary in central Japan (after Huzita).

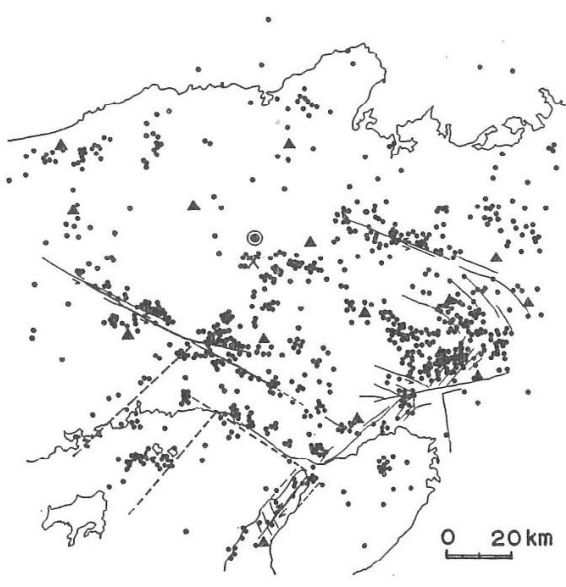

Fig. 15. Distribution of microearthquakes and active fault system in the northwestern part of Kinki district (after Kishimoto and Huzita).

\section{$5 \cdot 2$ 地殼応力}

近畿西部においては, 藤田らの横ずれ活断層解析に よると，Fig. 14 に示すように，山崎・三峠断層など の NW-SE 方向に延びる左ずれ之， それに共役な六 甲山地断層系たと党ば五助橋断層など NE-SW の方 向の断層が存在し，これらは部分的に右ずれる示して いる。また，岸本らがこの付近で観測した微小または 小地震の震央分布を示すと，Fig. 15 のようで，上記 の共役断層に沿ら分布が認められる。上のことから， この付近も，現在，東西圧縮の場にあると結論される。 一等三角測量から得られた主ひずみみ，Fig. 5 か らわかるよらに, やはり東西方向である。さらに,

Fig. 10 に示した起震力の方向も，この付近では，概 して東西方向である。微小地震の発震機構についても 同じ結果が得られている。

奥多々良木南方 $7 \mathrm{~km}$ に生野鉱山が岕るが，ここで は，1969年から72年にかけて，山は就数回起こり， これらが敷小地震観測網にとらえられた。これらの山 はね震動のP波初動分布から，Fig. 16 に示すよら

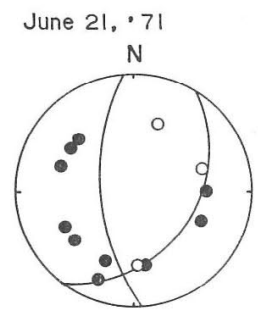

- Push, Pull

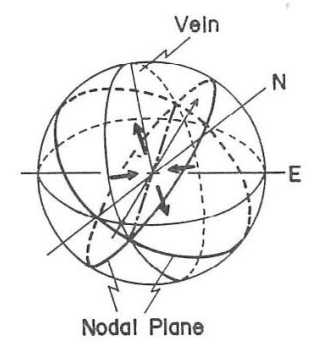

Nodal Plane
Fig. 16. Push-pull distribution of initial motion of ground tremors caused by rock burst in the Ikuno mine (left) and its mechanism diagram (right). 
な発震機構が求められた。この結果から,これらの山 はね秋, 東西方向の圧縮力による dip-slip 型の破壞 であろらと考觉られる。だだし，このことは，たまた ま採掘された銿面の走行がNSであることに関係して いたとも考えられる。

$$
6 \text { 結言 }
$$

新高瀬川拈よび奥多々良木地下発電所の建設工事の 際測定された地山応力と地学的方法によって推定され た地殼応力とを比較し, 両者の主応力方向はほぼ一致 することを認めた，従来の経験によれば, 地山応力測 定值は数十 $\mathrm{cm}$ 程度離れてもいくぶえ異なることが多 く，また応力解放法そのものの信頼性は高くないこと を認めなければならない。乙かし，今回の検討により， 地山応力測定法はある程度の信頼性が高められたもの と考学る。

最後に, 資料の提供を賜わった東京電力（株）御牧 陽一氏, 関西電力 (株) 吉田 登氏・錦織達郎氏, 鹿 島建設 (株) 技術研究所岡林信行氏に深甚なる謝意を 表する次第である.

(昭和48年11月24日 第 4 回岩の力学シンポジウムにて講演)

参 考文 献

1）岡 行俊, 平松良雄, 日本鉱業会誌, 84, 7 (1968).
2）御牧陽一，第 8 回岩盤力学シンポジウム講演概要， 67 (1973).

3) 平山次郎, 垣見俊弘, 地球科学, 78, 23 (1965).

4) 原田健久, 葛西篤男, 測地学会誌, 17, 4 (1971).

5) Kasahara, K., and A. Sugimura, J. Geodetic Soc. Japan, 10, 139 (1964).

6) 池田 進, トンネルと地下，3，10，1 (1972).

7）平松良雄, 岡 行俊, 菅原勝彦, 日本鉱業会昭和 47 年秋 季大会分科研究会資料 $B-8$.

8）芥川真知, 岡林信行, 谷本治重, 青木謙治, 福岡 孝, 鹿島建設技術研究所年報, 21, 123 (1973).

9) Ichikawa, M., Geophys. Mag., 35, 207 (1971).

10）錦織達郎，第 8 回岩盤力学シンポジウム講演概要， 72 (1973).

11）北原義浩, 金川 忠, 電力中央研究所技術第二研究所報 告, 依頼報告 71525 (1971).

12) 藤田和夫, 岸本兆方, 科学, 42, 422 (1972).

13) Huzita, K., Y. Kishimoto, and K. Shiono, J. Geosciences, Osaka City Unıv., 16, 93 (1973̈).

14) Nishıda, R., Bull. Disas. Prev. Res. Inst., Kyoto Univ., 22, Part 3, 197 (1973).

15）中村正夫, 震研速報, 10 号, 第 5 冊, 10 (1973).

16）田中 豊, 西田良平, 京大防災研年報, 14 号 A, 149 (1971)；15号 B, 43 (1972). 